\title{
Tinjauan Fikih Muamalah terhadap Akad Ijarah Tanah Bengkok di Desa Cileungsir Kecamatan Rancah
}

\author{
Arif Budiman, Sandy Rizki Febriadi, Mohamad Andri Ibrahim \\ Program Studi Hukum Ekonomi Syariah, Fakultas Syariah, Universitas Islam Bandung \\ Jl. Tamansari No. 140116 \\ arifabbud56@gmail.com,prisha587@gmail.com, andriibrahim@unsiba.ac.id
}

\begin{abstract}
Abstarct-Ijarah according to the syara is a contract which contains the provision of a benefit compensating with certain conditions. Bengkok land is an asset belonging to the village that is lent to village officials during their tenure and has the right to be managed by them both in private management or leased to third parties. The ijarah (rent) agreement is very vulnerable when considering that the crooked is not the perfect property of village officials, but only the management right. This study aims to find out how the ijarah law in the view of fiqh muamalah, to find out how the perspective of fiqh muamalah regarding the practice of the benthic ijarah contract which is polemic in the middle of the contract period with the death of the village head in the village of Cileungsir, Rancah sub-district. The author hopes that this research can be an additional information in the world of education., This research is a qualitative research with a case study approach that is, the author conducts observations, and direct interviews with related parties according to the problem under study. The results showed that of the entire pillars of ijarah namely, aqidain, ma'qud 'alaih, ujrah, and shigat had been fulfilled except two of the other ijarah requirements namely, an-nafadz conditions (applicable conditions), and legal ijarah requirements where there were no blessings from the new village head for the continuation of the remaining contract which is now using his land rights, from the lack of pleasure resulting in the permit granted by the new village head was deemed invalid.
\end{abstract}

Keywords-Fiqh Muamalah, Ijarah, Bengkok Land.

Abstrak-Ijarah menurut syara adalah akad yang berisi pemberian suatu manfaat berkompensasi dengan syarat-syarat tertentu. Tanah bengkok merupakan aset milik desa yang dipinjamkan kepada aparat desa selama menjabat dan berhak untuk dikelola oleh mereka baik pengelolaan secara pribadi maupun disewakan kepada pihak ketiga. Akad ijarah (sewa) ini sangat rentan bila mengingat bengkok tersebut bukan merupakan hak milik sempurna aparat desa, melainkan hanya hak kelola saja. Penelitian ini bertujuan untuk mengetahui bagaimana hukum ijarah dalam pandangan fikih muamalah, untuk mengetahui bagaimana perspektif fikih muamalah mengenai praktik akad ijarah tanah bengkok yang mana terdapat polemik ditengah masa akad dengan meninggalnya kepala desa di desa Cileungsir kecamatan Rancah. Penulis berharap penelitian ini dapat menjadi sebuah informasi tambahan dalam dunia pendidikan. Penelitian ini adalah penelitian kualitatif dengan pendekatan studi kasus yakni, penulis melalukan observasi, dan wawancara langsung pada pihak-pihak terkait sesuai dengan permasalahan yang diteliti. Hasil penelitian menunjukan bahwa dari keseluruhan rukun ijarah yakni, aqidain, ma'qud 'alaih, ujrah, dan shigat telah terpenuhi kecuali dua diantara syarat ijarah lainnya yakni, syarat an-nafadz (syarat berlaku), dan syarat sah ijarah dimana tidak terdapat keridhoan dari kepala desa yang baru untuk keberlangsungan akad tersisa yang sekarang menggunakan hak tanahnya, dari ketidak ridhoan tersebut mengakibatkan izin yang diberikan kepala desa yang baru pun dianggap tidak sah.

Kata kunci-Fikih Muamalah, Ijarah, Tanah Bengkok.

\section{PENDAHULUAN}

Pertukaran jasa atau materi sudah diatur didalam syariat Islam dengan berbagai macam akad yang salah satunya merupakan akad Ijarah. Menurut Hanafiyah akad ijarah adalah akad atas manfaat dengan adanya kompensasi tertentu, Syafi'iyah mengartikan ijarah adalah akad atas manfaat tertentu yang diperbolehkan dengan nilai kompensasi tertentu, Menurut Hanabilah ijarah merupakan suatu akad atas manfaat yang bisa sah dengan lafadz ijarah dan kara' dan semacamnya.1 Akad ijarah seperti juga akad jual beli, termasuk bagian dari al-'uquud al-musammah (akad yang telah disebutkan namanya dan diatur oleh Allah) yang sangat diperhatikan hukumnya secara khusus oleh syariat Islam dari sisi karakter akadnya. Akad ijarah berbeda dengan transaksi jual-beli karena jual-beli bersifat permanen, sedangkan akad ijarah (sewa) bersifat temporal karena pengaruhnya tidak dapat memindahkan kepemilikan suatu barang2

Suatu akad di mana di dalamnnya terdapat perjanjian antara dua pihak dengan perjanjian untuk menyewakan manfaat baik itu manfaat dari suatu benda maupun jasa, dengan rincian pemilik jasa atau harta berhak mendapat bayaran dari penyewaannya, dan penyewa berhak mendapat manfaat dari apa yang telah dibayarkannya. Unsur yang terpenting dalam ijarah yaitu kedua belah pihak cakap bertindak dalam hukum, yaitu mampu membedakkan yang baik dan yang buruk. Imam AsySyafi'I dan Hambali menambahkan satu syarat lagi, yaitu dewasa (baligh). Sedangkan untuk sahnya perjanjian sewamenyewa harus terpenuhi syarat di antaranya, masingmasing pihak rela melakukan perjanjian sewa menyewa. 
Dalam penelitian yang dilakukan oleh (Achmad Mufid), tahun 2015 yang membahas mengenai tanah bengkok, dalam penelitiannya, dalam penelitian ini Achmad Mufid menitikberatkan penelitiannya dalam penyalahgunaan objek. Berbeda dengan penelitian (Ahmad Zakky Rusdianto), tahun 2015 dalam penelitiannya Ahmad memaparkan penelitian mengenai pengelolaan tanah bengkok terkait Undang-undang No.6 Tahun 2014 tentang desa, dalam penelitiannya Ahmad menjelaskan mengenai bagaimana urgensi tanah bengkok yang masih menjadi kompensasi gaji aparat desa, sedangkan penghasilan tetap aparat desa telah diatur dalam Undang-undang No.6 Tahun 2014. Dalam penelitian yang telah penulis paparkan, penulis merasa masih ada kekurangan teori pada penelitian diatas, kematian merupakan salah satu hal yang tidak dapat diprediksi dan pasti setiap orang akan mengalaminya, melihat dari hal itu penulis berusaha membuat penelitian mengenai bagaimana bila dipertengahan akad pihak aparat desa meninggal dunia, apakah akad bisa tetap berlanjut atau harus berhenti. Mengingat pendapat ulama Hanafiyah dimana ia menyatakan bahwa kematian salah satu pihak yang berakad menyebabkan akad berakhir.

Peristiwa yang terjadi di lapangan, saat di tengah masa sewa dengan masyarakat namun ada aparatur desa yang meninggal dunia tetapi masih terdapat hak penyewa akan tanah tersebut, maka akad akan tetap berlangsung hingga akhir jangka waktu sewa sesuai perjanjian, dengan cara hak kelola tanah diwariskan kepada ahli waris aparatur desa yang telah meninggal tadi. Padahal jika seorang aparat desa meninggal maka akan segera digantikan dengan aparatur desa yang baru, dan seharusnya hak tanah bengkok tersebut kembali kepada desa dan kemudian hak kelola tanah bengkok tersebut diberikan kepada aparatur desa yang baru. Namun dalam penelitian ini tidak demikian dan kemudian muncullah pertanyaan di kalangan masyarakat desa "apakah tanah bengkok dapat diwariskan?". Dari sini muncul kekhawatiran masyarakat khususnya petani yang tak memiliki lahan yang beranggapan bahwa, lahan tanah bengkok akan berkurang dan tidak dapat disewa lagi karena, tanah bengkok dapat diwariskan. Muncul pula kekecewaan aparatur desa pengganti karena, tanah bengkok yang seharusnya menjadi hak kelolanya sejak ia menjabat ternyata masih tertahan dan dikelola selama masa akad belum selesai oleh ahli waris aparatur desa yang sudah meninggal. Melihat polemik diatas maka praktik ijarah tanah bengkok harus diketahui terlebih dahulu sebelum dapat menyimpulkan hal tersebut benar atau salah. Kemudian, mengingat sistem yang digunakan berdasarkan syariat islam, maka peninjauan secara fiqih muamalah sangat dibutuhkan dalam praktik sewa tanah bengkok tersebut beserta polemiknya. Selanjutnya tujuan dalam penelitian ini diuraikan dalam pokok-pokok sebagai berikut:
1. Mengetahui konsep ijarah dakam fiqih muamalah.

2. Mengetahui praktik akad ijarah tanah bengkok di desa Cileungsir kecamatan Rancah.
3. Mengetahui tinjauan fikih muamalah terhadap akad ijarah tanah bengkok di desa Cileungsir kecamatan Rancah.

\section{LANDASAN TEORI}

\section{A. Konsep Ijarah}

Ijarah menurut syara adalah akad yang berisi pemberian suatu manfaat berkompensasi dengan syaratsyarat tertentu. Ijarah bisa juga didefinisikan sebagai akad atas manfaat yang dikehendaki, diketahui, dapat diserahkan, dan bersifat mubah dengan kompensasi yang diketahui. ${ }^{3}$ Akan tetapi akad ijarah terikat akan beberapa rukun dan syarat yang mana semua rukun dan syarat tersebut harus terpenuhi. Rukun ijarah:

1. Aqiadain adalah kedua belah pihak yang berakad.

2. Ma'qud 'alaih adalah barang atau jasa yang akan disewakan.

3. Ujrah adalah upah atas suatu pekerjaan atau biaya sewa atas suatu barang

4. Shigat adalah tercapainya akad melalui ijab dan Kabul.

Syarat ijarah:

1. Syarat wujud adalah syarat yang mengatur mengenai para pelaku akad dan mengatur kelangsungan akad itu sendiri.

2. Syarat an-Nafadz adalah adanya hak kepemilikan atau kekuasaan atas suatu benda.

3. Syarat sah adalah syarat yang mengatur mengenai kerelaan kedua pelaku akad, dan pemanfaatan objek akad. 4

Sistem ekonomi Islam tidak mengenal adanya kesepakatan perjanjian atau akad dimana salas satu pihak merasa tidak ridho atau terpaksa, sebagaimana yang telah dipaparkan dalam kaidah fikih berikut ini:

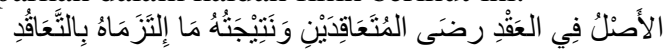

"Hukum asal dalam transaksi adalah keridhaan kedua belah pihak yang berakad, hasilnya adalah berlaku sahnya yang diakadkan".5

Dalam akad ijarah terdapat beberapa hal yang dapat mengakibatkan berakhirnya akad:

1. Meninggalnya pelaku akad (ulama Hanafiyah).

2. Adanya pengguguran akad.

3. Rusaknya barang yang disewakan sehingga ijarah tidak mungkin dilanjutkan.

4. Telah selesainya masa akad6 


\section{B. TANAH BENGKOK}

tanah bengkok merupakan aset desa yang digunakan untuk memberikan kompensasi/penghasilan bagi kepala desa dan perangkat desa karena jabatannya. Hak ini disebut sebagai hak asal usul yang melekat karena jabatan tersebut.7 Tanah bengkok digunakan oleh aparat desa sebagai tambahan penghasilan (tunjangan) dengan cara mengelolanya secara pribadi maupun disewakan kepada penduduk sekitar yang memerlukannya. Sejalan dengan peraturan pemerintah republik Indonesia nomor 47 tahun 2015 pasal 100 ayat 3 diterangkan mengenai fungsi tanah bengkok, yang berbunyi “ Hasil pengelolaan tanah bengkok atau sebutan lain sebagaimana dimaksud pada ayat (2) dapat digunakan untuk tambahan tunjangan kepala Desa dan perangkat Desa selain penghasilan tetap dan tunjangan kepala Desa sebagaimana dimaksud pada ayat (1) huruf b angka 1".

\section{HASIL PENELITIAN DAN ANALISA PEMBAHASAN}

A. praktik akad ijarah tanah bengkok di Desa Cileungsir Kecamatan Rancah

Penyewaan tanah bengkok pada pihak ketiga yang sejatinya merupakan barang pinjaman dari desa untuk aparat desa menurut fikih muamalah dibolehkan. Berdasarkan penjelasan al-Mawardi dalam kitabnya alHawi al-Kabir "tidak boleh peminjam menyewakan barang pinjaman yang ada padanya kepada orang lain tanpa izin dari pemilik barang.", hal ini menjadi boleh karena penyewaan tanah bengkok ini telah mendapat izin terlebih dahulu dari pihak kecamatan untuk disewakan. Dari data yang penulis peroleh, terdapat peristiwa dimana seorang kepala desa meninggal dunia saat baru 8 bulan menjabat dan terikat akad ijarah tanah bengkok dengan seorang warga selama 3 tahun. Dari sini kemudian dipilihlah kepala desa yang baru dengan musyawarah terlebih dahulu, mengingat tanah bengkok yang akan didapatkannya terikat akad dengan warga yang telah berakad dengan kepala desa sebelumnya, dalam musyawarah ini dibahas mengenai bagaimana keberlangsungan akad tersebut, akan tetap dilanjutkan atau diakhiri dengan cara ahli waris kepala desa sebelumnya membayar ganti rugi. Namun mengingat istri kepala desa sebelumnya hanyalah seorang ibu rumah tangga yang tidak berpenghasilan, maka kepala desa yang baru memutuskan untuk membiarkan akad tetap berlangsung. Namun dari wawancara dengan kepala desa yang baru, penulis memporoleh pernyataan bahwa beliau mengizinkan akad tersebut tetap berlangsung adalah karena terpaksa, untuk menjaga kredibilitasnya dimata masyarakat desa.

\section{B. Tinajuan fiqih muamalah terhadap praktik akad ijarah tanah bengkok di Desa Cileungsir Kecamatan Rancah}

Dari pernyataan tersebut, Yang digunakan penulis untuk menganalisis sewa menyewa tanah bengkok yaitu syarat an-nafadz, dan keridhoan antara pelaku sewa, yang mana syarat ini mengharuskan suatu manfaat tersebut dimiliki oleh pemberi sewa sehingga akad bisa berjalan dengan lancer sesuai dengan rukun dan syarat ijarah. Diperkuat dengan pendapat Hanafiah dan Malikiyah dimana, ijarah adl-fudul atau ijarah yang dilakukan oleh orang yang tidak memiliki kekuasaan atau tidak diizinkan oleh pemiliknya, statusnya mauquf (ditangguhkan) menunggu persetujuan si pemilik barang. Jika hal ini dikaitkan dengan peristiwa praktik sewa menyewa tanah bengkok yang kepala desanya atau dalam hal ini adalah yang menyewakan meninggal dunia serta kepala desa yang baru sudah terpilih, maka sewa menyewa yang dilakukan oleh kepala desa lama kemudian sudah dilanjutkan oleh ahli warisnya berhenti sampai kepala desa yang baru memberi izin untuk melanjutkan sisa jangka waktu sewa menyewa tanah bengkok tersebut. Kemudian keridhoan antara tiap pihak pun harus dipertimbangkan, dari wawancara yang penulis peroleh dari kepala desa yang baru, penulis menemukan bahwa kepala desa yang baru sebenarnya merasa tidak rela dan keberatan jika hak tanah bengkoknya dipergunakan karena, kepala desa yang baru tidak mendapatkan ganti atas bengkok yang masih dipegang oleh ahli waris kepala desa sebelumnya, beliau hanya mendapatkan sisa bengkok kepala desa sebelumnya yang tidak terikat akad dengan pihak manapun.

Dari semua itu bisa disimpulkan bahwasannya sewa menyewa tanah bengkok yang terjadi saat pihak penyewa meninggal di Desa Cileungsir Kecamatan Rancah jika dianalisis dengan rukun dan syarat ijarah hukumnya menjadi batal, karena walaupun kepala desa yang baru memberi izin untuk melanjutkan sisa jangka waktu sewa menyewa tanah bengkok tersebut, tetapi jika diperhatikan pada sisi keridhoan izin tersebut menjadi tidak berarti sesuai dengan kaidah fikih berikut ini.

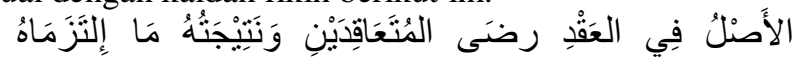

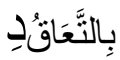

"Hukum asal dalam transaksi adalah keridhaan kedua belah pihak yang berakad, hasilnya adalah berlaku sahnya yang diakadkan ,8 


\section{SIMPULAN DAN SARAN}

\section{A. Simpulan}

Menurut hasil penelitian yang dilakukan yang penulis, maka dapat diambil kesimpulan sebagai berikut:

1. Praktik akad ijarah tanah bengkok yang dilakukan ketika pemilik hak kelola meninggal (kepala desa) saat akad belum selesai di desa Cileungsir kecamatan Rancah adalah, melanjutkan akad hingga selesai dengan cara pewarisan hak kelola bengkok kepada ahli waris kepala desa yang telah meninggal dan memberikan hak kelola sisa bengkok yang tidak terikat akad kepala desa sebelumnya kepada kepala desa yang baru.

2. Bila ditinjau dari segi fikih muamalah, akad ijarah tanah bengkok yang dilakukan ketika pemilik hak kelola meninggal (kepala desa) saat akad belum selesai di desa Cileungsir kecamatan Rancah ini dapat dikatakan batal karena, mengingat unsur antaradin walaupun kepala desa yang baru memberikan izin kepada ahli waris kepala desa sebelumnya untuk melanjutkan akad hingga selesai tetapi, dari hasil yang penulis dapat dari wawancara pada kepala desa yang baru. Diperoleh data bahwasannya beliau tidak rela akan pewarisan hak kelola tersebut, tetapi karna kepala desa yang baru takut akan kredibilitasnya turun di mata masyarakat maka kepala desa yang baru mengizinkan pelanjutan akad tersebut dengan berat hati.

\section{B. Saran}

Setelah menyimpulkan hasil dari penelitian, maka penulis ingin mengajukan saran-saran yang penulis harapkan dapat bermanfaat. Berikut adalah saran-saran yang penulis ajukan:

1. Pihak desa sebaiknya menyediakan tanah bengkok lain atau barang pengganti lainnya yang dapat dipergunakan aparat desa yang baru agar jika kejadian serupa terulang kembali, aparat desa yang lama bisa meng-ikhlas-kan tanahnya yang mungkin masih ada akad yang belum selesai dengan aparat desa sebelumnya

2. Disisi lain ada baiknya jika tanah bengkok dipergunakan untuk keperluan desa saja atau dijadikan media agar masyarakat bisa memanfaatkan tanah tersebut. Mengingat bahwa para aparatur desa telah memiliki penghasilan tetap walaupun masih terbilang sedikt dibandingkan dengan pns kota.

\section{DAFTAR PUSTAKA}

[1] al-Nadwi, Ahmad. al-Qawa'id al-Fiqhiyah. Beirut: Dar alQalam, 1998.

[2] Djuwaini, Dimyauddin. Pengantar Figh Muamalah Yogyakarta: Pustaka Pelajar, 2008.

[3] Hartanto, Dwiyana Achmad. Kedudukan Tanah Bengkok Sebagai Hak Asal-Usul Pasca Undang-Undang Nomor 6 Tahun 2014 Tentang Desa. Jurnal Mahkamah, 2016.

[4] Rozalinda. Fikih Ekonomi Syariah: Prinsi dan Implementasinya pada Sektor Keuangan Syariah. Jakarta: Raja Grafindo, 2016.

[5] Zuhaili, Wahbah. al-Fiqhu Asy-Syafi'i al-Muyassar. Jakarta: Almahira, 2010

[6] _. Fiqih Islam wa-Adillatuhu. Bandung: Gema Insani, 2011.

[7]

[8] Muhammad Natsir, Metode Penelitian, CV Bumi Aksara, Jakarta, 2000

[9] Nur Chamid, Jejak Langkah Sejarah Pemikiran Ekonomi Islam, Pustaka Azzam, Jakarta, 2011.

[10] Pusat Pengkajian dan Pengembangan Ekonomi Islam (P3EI) dan UII, Ekonomi Islam, Yogyakarta : UII Press, 2006.

[11] Uus Rustiman, Naskah Al Amwal ; Suntingan Teks \& Kajian Pemikiran Ekonomi Islam Abu Ubaid Tentang Keuangan Publik, Desertasi, Universitas Padjadjaran, 2017.

[12] Wahbah Azzuhaili, Fiqih Islam Wa Adillatuhu, jilid V, cet.X, Damaskus: Darul Fikr, 2007.

[13] Zainul Arifin, Dasar-Dasar Menajemen bank Syariah,cet.IV, Pustaka Alvabet, Jakarta, 2006. 